\title{
Aboriginal Ceramic Wares from Sites in the Yegua Creek Drainage of the Brazos River Basin, East Central Texas
}

Timothy K. Perttula

Follow this and additional works at: https://scholarworks.sfasu.edu/ita

Part of the American Material Culture Commons, Archaeological Anthropology Commons, Environmental Studies Commons, Other American Studies Commons, Other Arts and Humanities Commons, Other History of Art, Architecture, and Archaeology Commons, and the United States History Commons

Tell us how this article helped you.

This Article is brought to you for free and open access by the Center for Regional Heritage Research at SFA ScholarWorks. It has been accepted for inclusion in Index of Texas Archaeology: Open Access Gray Literature from the Lone Star State by an authorized editor of SFA ScholarWorks. For more information, please contact cdsscholarworks@sfasu.edu. 


\section{Aboriginal Ceramic Wares from Sites in the Yegua Creek Drainage of the Brazos River Basin, East Central Texas \\ Creative Commons License \\ (c) (1) (9)}

This work is licensed under a Creative Commons Attribution-NonCommercial 4.0 International License 


\title{
Aboriginal Ceramic Wares from Sites in the Yegua Creek Drainage of the Brazos River Basin, East Central Texas
}

\author{
Timothy K. Perttula
}

\section{Introduction}

Sherds from aboriginally-made ceramic vessels have been recovered on sites dating after ca. 2000 years B.P. in the Yegua Creek drainage of the Brazos River basin in the Post Oak Savannah of Burleson, Lee, and Washington counties in east central Texas (Figure 1). These sherds are from several different wares, including sandy paste Goose Creek Plain sherds made by Mossy Grove peoples, ancestral Caddo tempered and decorated wares made in East Texas, bone-tempered sandy paste wares that may be representative of a local ceramic tradition, and bone-tempered sherds from Leon Plain vessels made by Central Texas Toyah phase peoples. None of the ceramic sherd assemblages from the 18 sites discussed herein are substantial, ranging only from 1-72 sherds per site (with an average of only 13.3 sherds per site), indicating that the use (much less their manufacture) of ceramic vessels by Post Oak Savannah aboriginal peoples was not of much significance in their way of life, but may signify interaction, trade, and exchange between them and other cultures, such as the Caddo, inland and coastal Mossy Grove, and Toyah phase peoples that relied on ceramic vessel manufacture and use as key parts of their subsistence pursuits. It is likely that the benefits of trade (ceramics being just one of the items that was being traded) between these different peoples was to help establish cooperative alliances, and reduce competition and violence in the region, and such alliances were established and maintained by aboriginal peoples over a long period of time in the region.

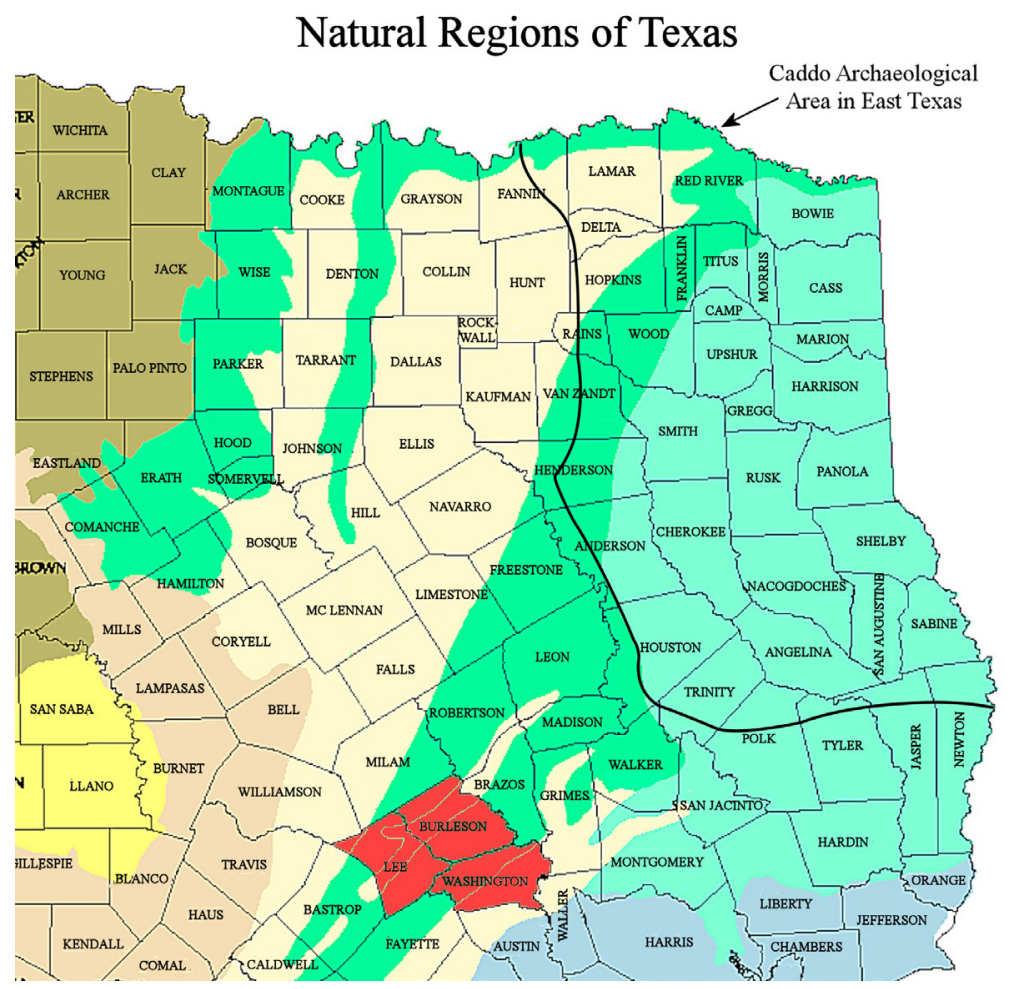

Figure 1. Burleson, Lee, and Washington counties in east central Texas. Figure provided by Lance Trask. 
This area was a cross roads or amalgam of different and diverse aboriginal ceramic traditions (see Perttula and Ellis 2013). This article reviews the character of the ceramic vessel sherds that have been found and reported from Yegua Creek and Brazos River sites in this part of the Post Oak Savannah, based on the review of published reports as well as the detailed examination of a sherd collection held by the Texas Archeological Research Laboratory at The University of Texas at Austin (TARL).

\section{Reading Site (41BU16) along the Brazos River}

Excavations at this Brazos River site in Burleson County recovered 72 ceramic vessel sherds from different wares (Roemer and Carlson 1987). These include thin sandy paste Goose Creek Plain vessel sherds $(n=33)$, plain sandy paste sherds with bone temper $(n=15)$, plain sandy paste sherds with grog temper $(\mathrm{n}=6)$, and 18 decorated sherds. Two Goose Creek Plain, var. unspecified sherds were also recovered at the Reading site during test excavations (Denton 1983). Two of the decorated sandy paste sherds have either a red slip or vertical-horizontal engraved lines (cf. Holly Fine Engraved), while the other decorated sherds are from grog-tempered $(n=8)$ or bone-tempered $(n=8)$ vessels. These latter sherds are from ancestral Caddo East Texas wares dating from ca. A.D. 900-1400), and include sherds with parallel and opposed incised lines and engraved elements with panels and cross-hatched zones as well as a red pigment rubbed in the engraved lines (see Roemer and Carlson 1987:Figures 28d-e, 29a-c, and 30c).

\section{Winnie's Mound (41BU17)}

This Brazos River aboriginal site has five Goose Creek Plain, var. unspecified sherds with a sandy paste. One rim sherd was from a vessel with an estimated $36 \mathrm{~cm}$ orifice diameter (Bowman 1985:50). The archaeological deposit is estimated to date from ca. A.D. 700-1200 (Bowman 1985:63).

\section{$41 B U 51$}

This ceramic-bearing aboriginal site is located on Old River, a relic channel of the Brazos River. Old River joins with the Brazos near its confluence with Yegua Creek (Broehm et al. 2010). During the data recovery investigations, nine Goose Creek Plain, var. unspecified rim and body sherds were found in the archaeological deposits (Broehm et al. 2010:46 and Figure 4.5a-c). Calibrated radiocarbon dates ranging between A.D. 658-783 and A.D. 1027-1191 may pertain to the estimated age of the ceramic sherds (Broehm et al. 2010:Table 5.1).

\section{Test Excavations at $41 \mathrm{BU75}$}

This site is on the Brazos River ca. $23 \mathrm{~km}$ from the confluence of the Brazos River and Yegua Creek (McWilliams et al. 2014). Test excavations there recovered six ceramic vessel sherds including three sandy paste Goose Creek Plain, var. unspecified rim and body sherds, a bone-tempered sandy paste body sherd with a single tool punctation (possibly Goose Creek Punctated), and two grog-tempered rim and body sherds from ancestral Caddo vessels (McWilliams et al. 2014:Table 2). The grog-tempered rim sherd is from a likely post-A.D. 1400 Maydelle Incised jar with cross-hatched incised lines (McWilliams et al. 2014:Figure 4a). 


\section{Lake Somerville Sites, Burleson County}

\section{Erwin's Bridge (41BU1)}

The Erwin's Bridge site is located on an alluvial terrace at the confluence of First Yegua and Middle Yegua creeks in the upper part of Lake Somerville (Honea 1961:Figure 1). Areas A ( $n=13)$ and B $(n=15)$ at the site both have aboriginal ceramic vessels, either from surfaces collections in both areas or limited excavations in Area A (Honea 1961; Peterson 1965:4). I was hoping to reanalyze the sherds from the Erwin's Bridge site as part of this article, but the sherd collection could not be relocated at the Texas Archeological Research Laboratory (Annie Riegert, May 10, 2019 personal communication).

In Area A, the ceramic sherds as described by Peterson (1965) are primarily from Goose Creek Plain, var. unspecified vessels $(\mathrm{n}=10)$. Other sherds in this area include one from a plain grog-tempered vessel and two from plain bone-tempered sandy paste vessels. Goose Creek Plain, var. unspecified sherds are also common in Area $B(n=7)$, along with three plain bone-tempered sandy paste sherds, and five plain grog- and grog-bone-tempered ancestral Caddo vessel sherds, likely from a vessel made by an East Texas Caddo community.

\section{$41 B U 4$}

41BU4 is on an alluvial terrace above the Middle Yegua Creek floodplain. Surface collections by Honea (1961:16) produced one plain sandy paste sherd from a Goose Creek Plain, var. unspecified vessel.

\section{$41 B U 9$}

This site is just to the north of 41BU4 on the same alluvial terrace landform (Honea 1961:19). A plain sandy paste sherd was also collected here during the Lake Somerville archaeological survey.

\section{Lake Somerville State Park Sites, Burleson County}

Work by Thoms (2004) recovered 12 aboriginal ceramic sherds from four sites in Burleson County at Lake Somerville State Park, specifically in the Birch Creek Unit. This includes two sherds from 41BU61, four sherds from 41BU63, three sherds from 41BU67, and three sherds from 41BU69 (Thoms 2004:Table 8). Although the temper and/or paste of each of the sherds is not provided, it appears that they are all from Goose Creek Plain, var. unspecified vessels (see Aten 1983; Aten and Bollich 2002; Story 1990).

\section{$41 B U 61$}

The two sherds from 41BU61 described by Thoms (2004) are from thin-walled vessels (mean thickness of $6.77 \mathrm{~mm}$ ), one of which has charred organic residue preserved on the interior surface of the sherd. The other sherd is from a vessel that was incompletely oxidized during firing. 
April 2019 investigations by Texas Parks \& Wildlife Department archaeologists at 41BU61 recovered a single decorated body sherd from the surface of the site (Aina Dodge, April 2019 personal communication). The sandy paste sherd has rows of fingernail punctations (Figure 2) and is from a Goose Creek Punctated vessel (see Perttula 2018). Goose Creek Punctated, and other decorated sandy paste Goose Creek ceramics, likely dates primarily after ca. A.D. 900 (see Aten 1983:Figure 14.5), at least in Mossy Grove sites in Southeast Texas.

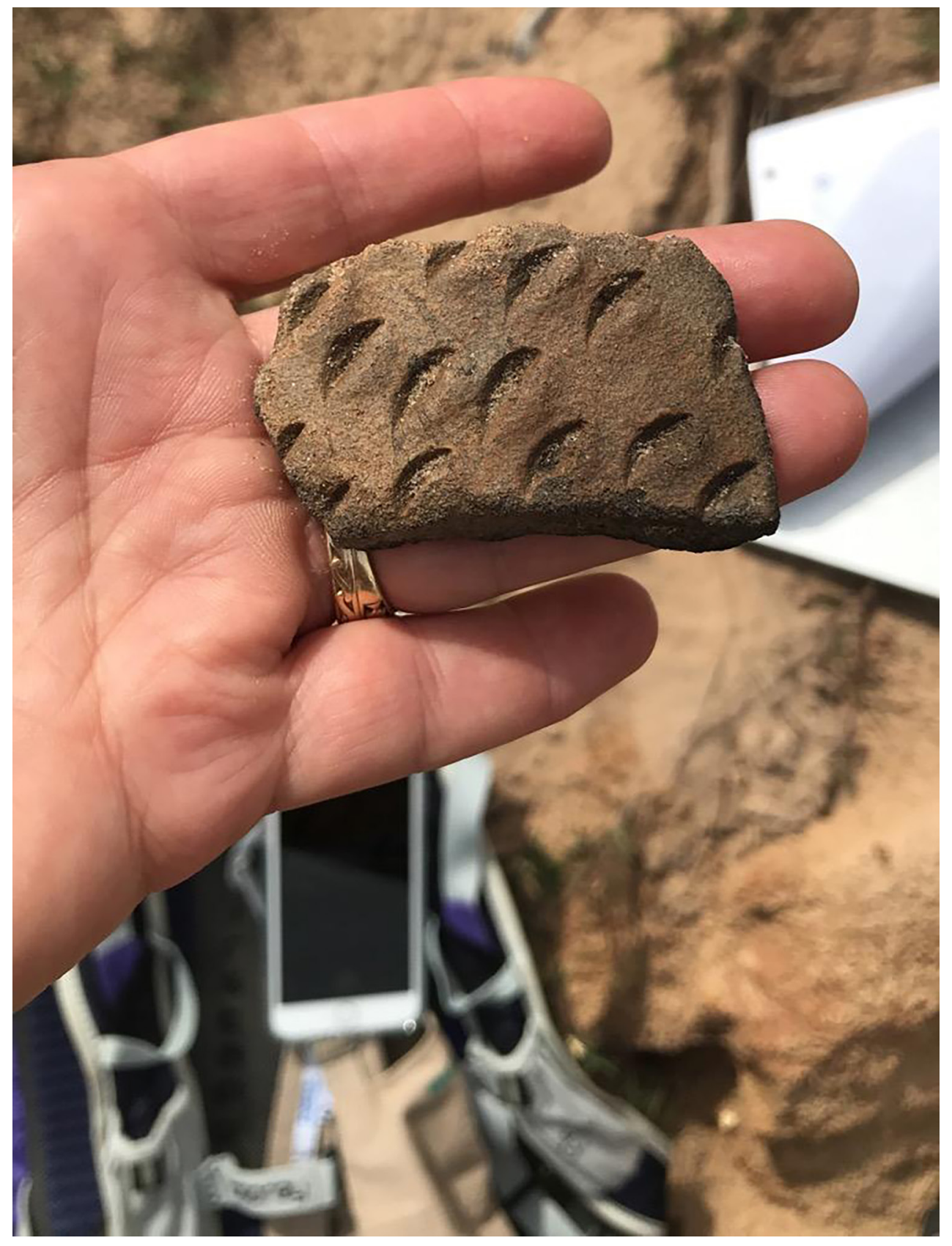

Figure 2. Goose Creek Punctated body sherd from 41BU61. Image courtesy of Texas Parks and Wildlife Department. 


\section{$41 B U 63$}

Two of the sherds are rim sherds from a plain jar with a ca. $12 \mathrm{~cm}$ orifice diameter. Two other sherds have large quartz grains (ca. 4-5 $\mathrm{mm}$ in size) in the paste. The sherds range from 4.96-5.95 $\mathrm{mm}$ in thickness.

\section{$41 B U 67$}

The ceramic vessel sherds are also from thin-walled vessels, ranging for body sherds from 5.32-5.64 $\mathrm{mm}$ in thickness, and 8.51 for the one base sherd in the collection. One of the sherds is from a vessel that was incompletely oxidized during firing.

\section{$41 B U 69$}

One rim sherd ( $4.96 \mathrm{~mm}$ in thickness) from the sherd is from a plain bowl with a ca. $20 \mathrm{~cm}$ orifice diameter and with hematite in the paste. One body sherd (5.15 $\mathrm{mm}$ in thickness) also has hematite inclusions in the paste, and the other is from a jar (5.54 $\mathrm{mm}$ thick) with a floated surface.

\section{Lake Somerville Sites, Lee County}

$41 L E 16$

Three ceramic vessel sherds from this aboriginal site near Middle Yegua Creek were collected during the Lake Somerville archaeological survey (Honea 1961:25). The sherds are plain bone-tempered sandy paste wares.

$41 L E 18$

This site, between Nails and Cedar creeks, both tributaries of Middle Yegua Creek, had one ceramic vessel sherd in a surface collection. It is a grog-tempered sherd (Honea 1961:27) likely from an ancestral East Texas Caddo vessel.

\section{Lake Somerville State Park, Lee County}

\section{LE69}

A single sandy paste body sherd (ca. $5.5 \mathrm{~mm}$ thick) from a Goose Creek Plain, var. unspecified vessel was collected from 41LE69 in the Nails Creek valley of the Middle Yegua Creek basin during a 1983 well pad survey (Texas Historic Sites Atlas, accessed April 22, 2019). The sherd was described as smoothed on both interior and exterior surfaces.

\section{Chesser Site (41LE59), Yegua Creek Basin}

The one ceramic vessel sherd from the Chesser site is a Goose Creek Plain, var. unspecified body sherd with a floated exterior surface. The sherd came from deposits radiocarbon dated to between ca. A.D. 450-900 (Rogers and Kotter 1995:Table 12).

\section{Boriack Bog, Middle Yegua Creek, Lee County}

The aboriginal ceramic vessel sherd assemblage $(n=71)$ at the Boriack Bog locality is almost exclusively from thin-walled (6.46-6.54 $\mathrm{mm}$ in mean thickness for rim and body sherds) bone-tempered vessels (93 percent), with a few from grog and/or hematite-tempered vessels (Perttula 2009). Many of 
the sherds have smoothed or burnished surfaces, and are from vessels fired in a low oxygen or reducing environment. Two of the sherds have brushing or brushed-incised marks, suggesting the occupation here took place after ca. A.D. 1200, when brushed utility ware first began to be manufactured in the region, while 11 body sherds (from at least six different vessels) have an interior red slip or red wash, and are possibly from Toyah phase Doss Red vessels.

\section{Unrecorded Site at Lake Somerville, Washington County}

Keith Honea in 1961 collected 18 sherds from an unrecorded site in Washington County as part of the archaeological study of Lake Somerville (see Honea 1961). These sherds are in the TARL collections. The sherds are from three different wares: sandy paste Goose Creek Plain, var. unspecified rim and body sherds $(n=5)$; tempered rim and body sherds from ancestral Caddo vessels $(n=7)$; and bone-tempered (probably Leon Plain) body sherds $(\mathrm{n}=6)$ (Table 1$)$.

Table 1. Detailed analysis of sherds from Lake Somerville site in Washington County, Texas.

\begin{tabular}{|c|c|c|c|c|}
\hline Sherd type & $\begin{array}{l}\text { Firing } \\
\text { conditions }\end{array}$ & $\begin{array}{l}\text { Surface } \\
\text { Treatment }\end{array}$ & $\begin{array}{l}\text { Thickness } \\
\text { (in } \mathrm{mm} \text { ) }\end{array}$ & $\begin{array}{l}\text { Decoration (if any); rim } \\
\text { form }\end{array}$ \\
\hline
\end{tabular}

Sandy paste

$\begin{array}{lllll}\text { Rim } & \text { B } & \text { E SM } & 6.0 & \text { Plain; direct rim-rounded lip } \\ \text { Body } & \text { B } & \text { E SM } & 6.7 & \text { Plain } \\ \text { Body } & \text { H } & - & 4.6 & \text { Plain } \\ \text { Body } & \text { F } & - & 8.2 & \text { Plain } \\ \text { Body } & \text { G } & \text { I/E SM } & 5.9 & \text { Plain }\end{array}$

\section{Grog-bone-tempered}

\begin{tabular}{|c|c|c|c|c|}
\hline Body & $\mathrm{H}$ & I SM & 6.2 & Parallel incised lines \\
\hline Body & $\mathrm{F}$ & I SM & 6.5 & $\begin{array}{l}\text { Parallel brushed marks-linear } \\
\text { tool punctations pushed } \\
\text { through the brushing }\end{array}$ \\
\hline Body & $\mathrm{F}$ & I SM & 6.0 & $\begin{array}{l}\text { Parallel brushed marks-linear } \\
\text { tool punctations pushed } \\
\text { through the brushing }\end{array}$ \\
\hline Body & B & I SM & 5.4 & Parallel brushed marks \\
\hline Body & B & - & 4.5 & Plain \\
\hline
\end{tabular}

\section{Bone-hematite-tempered}

$\begin{array}{lllll}\text { Rim } & \text { B } & - & 6.4 & \begin{array}{l}\text { Vertica } \\ \text { marks } \\ \text { appliqued } \\ \text { and ro }\end{array} \\ \text { Body } & & & & \text { Plain } \\ \text { Bone-tempered } & \text { F } & - & 7.6 & \\ \text { Body } & & & & \\ \text { Body } & \text { F } & - & 6.0 & \text { Plain } \\ \text { Body } & \text { G } & - & 6.8 & \text { Plain } \\ \text { Body } & \text { C } & - & 5.4 & \text { Plain } \\ \text { Body } & \text { B } & - & 7.3 & \text { Plain } \\ \text { Body } & \text { G } & \text { I SM } & 7.5 & \text { Plain } \\ & \text { C } & \text { E SM } & 5.2 & \text { Plain }\end{array}$

Firing conditions (see Teltser 1993:Figure 2; Perttula 2005:Figure 5-30): B=fired and cooled in a reducing environment; $\mathrm{C}=$ incompletely oxidized during firing; $\mathrm{F}-\mathrm{H}=$ fired in a reducing environment and cooled in the open area Surface treatment: E SM=exterior smoothed; I=interior smoothed; I/E SM=interior/exterior smoothed 
The sandy paste Goose Creek Plain sherds are from vessels fired in a reducing environment (and several were then cooled in the open air), and with thin vessel walls (4.6-8.2 $\mathrm{mm}$ thick, with a mean thickness of $6.28 \mathrm{~mm}$ ), and smoothed on either exterior $(\mathrm{n}=3)$ or interior $(\mathrm{n}=1)$ vessel surfaces (see Table 1). The one rim has a direct profile and a rounded lip.

The seven ancestral Caddo sherds in the collection are from grog-bone-tempered $(n=5)$ or bonehematite-tempered $(n=2)$ vessels. Five of the sherds are from utility ware jars with parallel brushed marks $(n=1)$, parallel brushed-linear tool punctated rows through the brushing marks $(n=2)$, vertical brushed-incised marks and lines and a vertical appliqued fillet $(n=1)$, and parallel incised lines; the other two sherds are plain. The predominance of brushed marks in the small decorated sherd assemblage suggests these ancestral Caddo sherds are from post-A.D. 1400 Caddo jars, including Bullard Brushed and Maydelle Incised (see Suhm and Jelks 1962), likely made in the upper Neches River basin by Frankston phase Caddo potters (see Perttula 2013) and traded/exchanged with the aboriginal inhabitants of the Yegua Creek basin.

The Caddo sherds are from vessels fired in a reducing environment (again with several from vessels cooled in the open air), and have interior smoothed surfaces (see Table 1). The mean thickness of these sherds is $6.1 \mathrm{~mm}$. The one rim sherd (brushed-incised-appliqued fillet) has a direct profile and a rounded lip.

The bone-tempered wares are also from thin-walled vessels, likely from Leon Plain vessels made by Central Texas Toyah phase peoples (see Kenmotsu and Boyd 2012:12), with a mean thickness of 6.37 $\mathrm{mm}$. They are from vessels either fired in a reducing environment $(\mathrm{n}=4)$ or incompletely oxidized during firing $(n=2)$. Two of the sherds have been smoothed on either interior or exterior vessel surfaces (see Table 1).

\section{Washington-on-the-Brazos Site (41WT5)}

The aboriginal sherds recovered at the Washington-on-the-Brazos (41WT5) site are primarily from fine to coarse sandy paste Goose Creek Plain, var. unspecified vessels $(\mathrm{n}=9)$ with smoothed to floated surfaces and 4.0-7.0 $\mathrm{mm}$ thick body walls (Brewington 1995). One sandy paste body sherd is from a Goose Creek Incised vessel with parallel incised lines.

\section{Summary and Conclusions}

This article considers the occurrence and character of aboriginal ceramic vessel sherds found in sites in the Yegua Creek and Brazos River basins in Burleson, Lee, and Washington counties in the Post Oak Savannah of East Central Texas, and their implications with respect to the development of local ceramic traditions as well as the interaction and exchange between aboriginal peoples represented by sherds from different ceramic wares. Observations on the ceramic vessel sherds are based on both descriptions in published reports or reports on file at TARL, as well as the detailed examination of one sherd assemblage curated at TARL.

There are four different ceramic wares represented in the assemblages from Yegua Creek and the Brazos River basin in present-day east central Texas, dating from as early as ca. 2000 years ago to at least 500 years ago. Ceramic vessels are not common on sites in this part of Texas, but the existence of different manufacturing (and decorative) traditions in the region suggests both the development of localized ceramic practices as well as broad scale interactions with neighboring groups (such as ancestral Caddo peoples) with different ceramic traditions (Perttula and Ellis 2013:130).

The ceramic wares in the Yegua Creek and Brazos River basins are: sandy paste Goose Creek Plain and Goose Creek decorated sherds ( $\mathrm{n}=98,41$ percent of the sherds in the various collections) from 15 of the 18 sites discussed herein; bone-tempered plain and decorated sherds ( $\mathrm{n}=75,31.4$ percent) from only 
two sites; bone-tempered sandy paste sherds ( $\mathrm{n}=24,10$ percent) from four sites; and tempered plain and decorated ancestral Caddo ceramic sherds ( $\mathrm{n}=42,17.6$ percent) from six of the 18 sites. The Goose Creek ceramics, first made ca. 2500 years ago (Perttula 2008:Table 7-40), have a sandy paste, thin walls, floated surfaces, and rounded or conical bases and are associated with the Mossy Grove Culture (Ellis 2013:141 and Figure 1). Decorated sandy paste pottery is generally rare (see Story 1990:Tables 58 and 64), and likely dates mainly after ca. A.D. 900 on area sites. Plain and decorated bone-tempered ceramic wares are apparently present throughout the region before the post-A.D. 1250 manufacture of Leon Plain pottery, as are bone-tempered sandy paste ceramics. Plain bone-tempered sandy paste ceramics have been recovered in pre-A.D. 400 and ca. A.D. 380-800 contexts in the Trinity and Navasota River basins (Perttula and Ellis 2013:125), while at Boriack Bog in Lee County, plain bone-tempered and bone-tempered sandy paste sherds occur together with brushed as well as red slipped or red-filmed sherds in post-A.D. 1200 contexts. Ancestral Caddo vessels tempered with grog and/or bone (and occasionally with a sandy paste, see Perttula 2008:421) that were manufactured in a number of different regions in East Texas were occasionally traded or exchanged with aboriginal hunter-gatherer groups whose territorial range included the Brazos and Colorado River basins, including the Lake Somerville and Lake Somerville State Park in the Brazos River basin, generally between ca. A.D. 900-1800. Post-A.D. 1400 Caddo ceramics are particularly widespread in the region, as at the Reading site (41BU16) on the Brazos River and a site in Washington County at Lake Somerville.

\section{Acknowledgments}

Thanks to Marybeth Tomka and Annie Riegert for their help in rounding up collections from Lake Somerville and Lake Somerville State Park held by the Texas Archeological Research Laboratory at The University of Texas at Austin. Thanks also to Aina Dodge (Texas Parks and Wildlife Department) for encouraging this study. Lance Trask prepared Figure 1 for this article.

\section{References Cited}

Aten, L. E.

1983 Indians of the Upper Texas Coast. Academic Press, New York.

Aten, L. E. and C. N. Bollich

2002 Late Holocene Settlement in the Taylor Bayou Drainage Basin: Test Excavations at the Gaulding Site (41JF27), Jefferson County, Texas. Studies in Archeology 40, Texas Archeological Research Laboratory, The University of Texas at Austin, and Special Publication No. 4, Texas Archeological Society, San Antonio.

Bowman, B. F.

1985 Winnie's Mound (41BU17): A Study in the Prehistory of Burleson County, Texas. Bulletin of the Texas Archeological Society 56:39-74.

Brewington, R. L.

1995 Prehistoric Pottery from Washington. In The Anson Jones Plantation: Archaeological and Historical Investigations at 41 WT5 and 41WT6, Washington County, Texas, edited by S. B. Carlson, pp. 207212. Reports of Investigations No. 2. Center for Environmental Archaeology, Texas A\&M University, College Station.

Broehm, C. J., J. K. McWilliams, R. C. Fields, and K. W. Kibler

2010 Testing and Data Recovery Excavations at 41BU51, Burleson County, Texas. Reports of Investigations No. 161, Prewitt and Associates, Inc., and Archeological Studies Program Report No. 124, Archeological Studies Program, Environmental Affairs Division, Texas Department of Transportation, Austin. 
Denton, J. T.

1983 Archaeological Testing of the Reading Site, Site 41BU16, Burleson County, Texas. Highway Design Division, Texas State Department of Highways and Public Transportation, Austin.

Ellis, L. W.

2013 Woodland Ceramics in East Texas and a Case Study of Mill Creek Culture Ceramics. Bulletin of the Texas Archeological Society 84:137-180.

Honea, K. H.

1961 Appraisal of the Archaeological Resources of Somerville Reservoir, Lee, Washington, and Burleson Counties, Texas. Texas Archeological Salvage Project, The University of Texas at Austin.

Kenmotsu, N. A. and D. K. Boyd

2012 The Toyah Phase in Texas; An Introduction and Retrospective. In The Toyah Phase of Central Texas: Late Prehistoric Economic and Social Processes, edited by N. A. Kenmotsu and D. K. Boyd, pp. 1-18. Texas A\&M University Press, College Station.

McWilliams, J. K., K. W. Kibler, J. E. Dockall, E. F. Gadus, and R. C. Fields

2014 Eligibility Testing at 41BU75, Burleson County, Texas (CSJ No. 0648-03-046). Technical Reports No. 96. Prewitt and Associates, Inc., and Archeological Studies Program, Report No. 159, Environmental Affairs Division, Texas Department of Transportation, Austin.

Perttula, T. K.

2009 Aboriginal Ceramics from the Boriack Bog Locality, Lee County, Texas. Houston Archeological Society Journal 132:37-41.

2013 Caddo Ceramics in East Texas. Bulletin of the Texas Archeological Society 84:181-212.

2018 The Strawberry Hill Site (41SJ160) Ceramic Vessel Sherd Assemblage, San Jacinto County, Texas, and Comparisons to other Mossy Grove Culture Ceramic Assemblages. Report No. 31. Houston Archeological Society, Houston.

Perttula, T. K. (editor)

2005 Archeological Investigations at the Pilgrim's Pride Site (41CP304), a Titus Phase Community in the Big Cypress Creek Basin, Camp County, Texas. 2 Vols. Report of Investigations No. 30. Archeological \& Environmental Consultants, LLC, Austin.

2008 Lake Naconche Archeology, Nacogdoches County, Texas: Results of the Data Recovery Excavations at Five Prehistoric Archeological Sites. 2 Vols. Report of Investigations No. 60. Archeological \& Environmental Consultants, LLC, Austin.

Perttula, T. K., and L. W. Ellis

2013 Aboriginal Ceramics Among Groups Living in the Prairie Savanna Region of Texas. Bulletin of the Texas Archeological Society 84:113-135.

Peterson, F. A.

1965 The Erwin's Bridge Site at Somerville Reservoir, Burleson County, Texas. Texas Archeological Salvage Project, The University of Texas, Austin.

Roemer, E., Jr. and S. B. Carlson

1987 Excavations at 41BU16: State Highway 21 at the Brazos River, Burleson County, Texas. Contract Reports in Archaeology, Report No. 1. Highway Design Division, Texas State Department of Highways and Public Transportation, Austin.

Rogers, R. and S. Kotter

1995 Archaeological Investigations at the Chesser Site (41LE59) at the Sandow Mine, Lee County, Texas. Document No. 950209. Espey, Huston \& Associates, Inc., Austin. 
Story, D. A.

1990 Cultural History of the Native Americans. In The Archeology and Bioarcheology of the Gulf Coastal Plain, by D. A. Story, J. A. Guy, B. A. Burnett, M. D. Freeman, J. C. Rose, D. G. Steele, B. W. Olive, and K. J. Reinhard, pp. 163-366. 2 Vols. Research Series No. 38. Arkansas Archeological Survey Research Series, Fayetteville.

Suhm, D. A. and E. B. Jelks (editors)

1962 Handbook of Texas Archeology: Type Descriptions. Special Publication No. 1, Texas Archeological Society and Bulletin No. 4, Texas Memorial Museum, Austin.

Teltser, P. A.

1993 An Analytic Strategy for Studying Assemblage-Scale Ceramic Variation: A Case Study from Southeast Missouri. American Antiquity 58(3):530-543.

Thoms, A. V. (editor)

2004 Yegua Creek Archaeological Project: Survey Results from Lake Somerville State Parks and Trailway, East-Central Texas. Reports of Investigations No. 5. Center for Ecological Archaeology, Texas A\&M University, College Station. 